\title{
Analyzing Industrial Water Demand in India: An Input Distance Function Approach
}

\author{
Surender Kumar
}

\begin{abstract}
This study investigates the water demand of Indian manufacturing plants. It adopts an input distance function approach and approximates it by a translog form. Duality between cost function and input distance function is exploited to retrieve information concerning substitutability and the shadow price of water. The model is estimated, using linear programming approach, on a sample of 92 firms over the three years. The results show that the average shadow price of water is rupees 7.21 per kilolitre and the price elasticity of derived demand for water is high, -1.11 on average, a value similar to what has been found by other researchers working on developing countries (for example, China and Brazil). This indicates that water charges may be an effective instrument for water conservation.
\end{abstract}

Key Words: input distance function, industrial water demand, translog form, water, price elasticity.

JEL Classification: C33, D20, Q25.

"Fellow, National Institute of Public Finance and Policy, 18/2 Satsang Vihar Marg, Special Institutional Area (Near JNU), New Delhi 110067. E-mail: surender@nipfp.org.in or surenderkumarbansal@hotmail.com The author wishes to thank Professor M.N. Murty, Institute of Economic Growth, Delhi for providing data and encouragements, and Professor B. N. Goldar and Dr. Kala S. Sridhar for their valuable comments and suggestions. 


\title{
Analyzing Industrial Water Demand in India: An Input Distance Function Approach
}

\author{
Surender Kumar
}

\section{Introduction}

Use of water may be broadly classified into three consumption categories: agricultural, industrial and domestic. While there is substantial literature dealing with the agricultural ${ }^{i}$ and domestic ${ }^{\mathrm{ii}}$ uses of water, relatively few have systematically analyzed industrial water use especially in the context of developing countries. ${ }^{\text {iii }}$ This may partly be due to the lack of reliable information on water consumption at the firm level. There is no consensus on the range of industrial water demand price elasticity and the sensitivity of water demand to other factors such as other input prices and output levels. The question of assessing the economic value (shadow price) of water still remains open.

There are several reasons for analyzing industrial water demand in developing countries. First, although current industrial withdrawal of water in developing countries is quite low in comparison to developed countries, this is expected to increase in comparison to other sectors of the economy as well as in absolute terms since these countries are expected to have higher growth in industrial production in the near future. Second, in developing countries, for toxic and some persistent organic pollution including heavy metals industry may be attributed most of effluent emissions and a large proportion of urban population lives in the vicinity of industrial areas and suffers the ill consequences of high level of water pollution. Third, in countries, like India, where concentration based environmental standards are adopted for water pollutants and financial extraction costs of water is too low, firms have incentives to dilute the effluent stream with the excessive use of water (Goldar and 
Pandey, 2001). Fourth, since water being a scarce input, there are conflicts over its allocation towards different uses, thus the valuation of water in competitive uses (domestic, industrial and agricultural; as well as within different industries or firms) is a prerequisite for any water resource policy design. Lastly, it is widely recognized that an appropriate pricing policy for water can lead to substantial saving in industrial water consumption. This is further possible with the application of water recycling and conservation technologies (Bhatia et. al., 1994).

Water enters into the production process of manufacturing firms as an intermediate public good, which reduces the unit cost of production, (Wang and Lall, 2002). Earlier studies on industrial water use, in estimating the demand models ${ }^{\text {iv }}$ have used the ratios of total expenditure to total quantities of water purchased as proxies for prices. In the cost function models, ${ }^{\mathrm{V}}$ studies were conducted by including water as input along with labour, capital and materials, and the average cost of water consumption is used to determine the price. These studies find that the price elasticities of water are small and industry specific. They also find that water and labour are mostly substitutes whereas capital and water are complementary inputs. The results of these studies should be considered with caution since they are based on aggregate data and do not take into account the specificity of water as input. Moreover, in these studies, the water quantity appeared on both sides of the demand equation that may introduce a simultaneity bias, and the use of average cost is not consistent with economic theory since firms respond to marginal prices in their decision making process.

This paper contributes to the literature on industrial water use by estimating the industrial water demand for a panel of Indian manufacturing firms observed from 1996/97 to 1998/99. We characterise the structure of industrial water demand by estimating a translog input distance function. We model production technology by distinguishing four inputs (material, labour, capital, and water) and one output (sales revenue). We are especially interested in analysing the following issues:

- What are the complementarity or substitutability relationships between the different inputs?

- What can be said about the price elasticity of industrial water demand in India?

- What can be the per unit shadow price of industrial use of water? 
A firm's production technology could be modeled in different ways: the production function, profit function or the cost function. Then Hotelling's Theorem and Shephard's Lemma allow one to derive compatible input demands and output offers with optimisation behaviour. Our approach to modelling the production process departs from earlier studies which use cost functions (see e.g., Reynaud, 2003; Feres and Reynaud, 2003) or production functions (see Wang and Lall, 2002; Goldar, 2003), and instead uses a distance function to measure technology. The input distance function completely describes multiple output technology and is dual to the cost function (Fare and Primont, 1995).

The input distance function has the obvious advantage over production functions in allowing for the possibility of multiple outputs and joint production. One advantage of the input distance function over the cost function is that no information on input prices is required, nor is the maintained hypothesis of cost minimisation required. In fact, no specific behaviour goal is embedded in the input distance function (Grosskopf et al., 1995). Moreover, the distance functions allow one to calculate the shadow prices of the inputs, as the observed prices of inputs in the developing countries are not market clearing prices especially for the commodities like water. Similar to other analyses of production and technology, we calculate ease of substitution among the various inputs. Using parameter estimates of input distance function, the Morishima and Allen elasticity of substitution are computed. The Morishima elasticity is viewed as more appropriate measure of substitutability when the production process has more than two inputs (Blackorby and Russell, 1989).

The remainder of the paper is organised as follows. Section 2 presents the economic modelling. Industrial production technologies are represented by the input distance function and are approximated by a translog form. The estimation model is the subject matter of section 3 . Then we present an empirical application. The model is applied on a panel data of 92 firms concerning different water polluting industries. The original data come from a survey conducted by the Institute of Economic Growth, Delhi, in 2000 and is presented in section 4. section 4 also presents and discusses the results of the study. The paper closes in section 5 with some concluding remarks. 


\section{Economic Model}

Consider a manufacturing firm employing a vector of inputs $\boldsymbol{x} \in \mathfrak{R}^{N}{ }_{+}$to produce a vector of outputs $\mathbf{y} \in \mathfrak{R}^{\mathrm{M}}{ }_{+}$where $\mathfrak{R}^{N}{ }_{+}, \mathfrak{R}^{M}$, are nonnegative $N$ - and $M$-dimensional Euclidean spaces, respectively. Let $P(\boldsymbol{x})$ be the feasible output set for the given input vector $\boldsymbol{x}$ and $L(\boldsymbol{y})$ is the input requirement set for a given output vector $\boldsymbol{y}$. Now the technology set is defined as (Fare et al. 1994)

$$
T=\left\{(\boldsymbol{y}, \boldsymbol{x}) \in \mathfrak{R}^{M+N}, \boldsymbol{y} \in P(\boldsymbol{x}), \boldsymbol{x} \in L(\boldsymbol{y})\right\} .
$$

The conventional production function defines the maximum output that can be produced from an exogenously given input vector while the cost function defines the minimum cost to produce the exogenously given output. The output and input distance functions generalise these notions to a multi-output case. The input distance function describes "how far" an input vector is from the boundary of the representative input set, given the fixed output vector. Formally, the input distance function is defined as

$$
D(\mathbf{y}, \mathbf{x})=\min \{\lambda:[\mathbf{x} / \lambda, \mathbf{y}] \in T\}
$$

Equation (2) characterises the input possibility set by the maximum equi-proportional contraction of all inputs consistent with the technology set (1). The input distance functions can be used to measure the Debreu-Farrell technical efficiency. The input distance function is homogeneous of degree one in inputs, concave in inputs, convex in outputs, and nondecreasing in inputs. ${ }^{\mathrm{vi}}$ It is dual to the cost function. That is:

$$
\begin{aligned}
& D(\mathbf{y}, \mathbf{x})=\min _{w}\{\mathbf{w} \mathbf{x}: C(\mathbf{y}, \mathbf{w}) \geq 1\} \\
& C(\mathbf{y}, \mathbf{w})=\min _{x}\{\mathbf{w x}: D(\mathbf{y}, \mathbf{x}) \geq 1\}
\end{aligned}
$$


Where $\mathbf{w}$ is a vector of minimum cost deflated input prices and $\mathrm{C}$ is a unit cost function if the costs are minimised. This implies that the value of input distance function would be equal to one only when the inputs are used in their cost minimising proportions, i.e.,

$$
C(\mathbf{y}, \mathbf{w})=\mathbf{w x} / D(\mathbf{y}, \mathbf{x})
$$

Both, cost function and input distance function, completely describes the production technology, they have different data requirements. Whereas, both require data on output quantities, the distance function requires data on input quantities rather than input prices. Applying the dual Shephard Lemma, the cost deflated (i.e., normalised) input shadow prices can be derived from the input distance function. Fare and Primont (1995) show that the cost deflated shadow price for each input is given by

$$
\mathbf{w}=C(\mathbf{y}, \mathbf{w}) \nabla_{x} D(\mathbf{y}, \mathbf{x})
$$

The undeflated (i.e., absolute) shadow prices can be expressed as the product of the cost function and the deflated shadow price. Hence when the cost function is known, the absolute shadow prices can be computed. The difficulty in computing undeflated shadow prices is the cost function depends on these undeflated shadow prices, which are unknown. However, if we assume that the observed price for the input is equal to its undeflated shadow price, then cost function is the ratio of its undeflated and deflated shadow prices. It is assumed that the undeflated shadow price of $x_{j}$ is equal to its observed market price. ${ }^{\text {vii }}$ The remaining undeflated shadow prices $\left(w_{i}\right)$ are computed as:

$$
w_{i}=w_{j} \frac{\partial D(\mathbf{x}, \mathbf{y}) / \partial x_{i}}{\partial D(\mathbf{x}, \mathbf{y}) / \partial x_{j}}, i \neq j
$$

Where $w_{i}$ and $w_{j}$ stands for the shadow prices of two different inputs $x_{i}$, and $x_{j}$ respectively. Equation (6) states the undeflated shadow price of input (e.g., water) is the product of the actual price of other input (e.g., materials) and the marginal rate of technical substitution (MRTS) between two inputs. According to this equation, the absolute shadow price of the input for an inefficient producer is determined by making a 
radial projection to the isoquant from the observation. ${ }^{\text {viii }}$ The shadow prices of the inputs associated with that observation are calculated at the point on the isoquant. Hence, the absolute shadow price reflects the actual proportions of inputs used by an inefficient producer.

As the input distance function completely describes the production technology and identifies the boundaries of technology, one may use it to describe the characteristics of the frontier or surface technology, including curvature, i.e., the degree of substitutability along the surface technology, (Grosskopf et. al., 1995). Therefore, we calculate indirect Morishima elasticity of substitution as defined by Blackorby and Russell (1989). That is:

$$
M_{i j}(\mathbf{x}, \mathbf{y})=\frac{d \ln \left[D_{i}(\mathbf{x}, \mathbf{y}) / D_{j}(\mathbf{x}, \mathbf{y})\right]}{d \ln \left[x_{i} / x_{j}\right]}=x_{i}\left(\frac{D_{i j}(\mathbf{x}, \mathbf{y})}{D_{j}(\mathbf{x}, \mathbf{y})}\right)-x_{i}\left(\frac{D_{i i}(\mathbf{x}, \mathbf{y})}{D_{i}(\mathbf{x}, \mathbf{y})}\right)
$$

where the subscripts on the distance functions refer to partial derivatives with respect to inputs: e.g., $D_{i i}(\mathbf{x}, \mathbf{y})$ is the second order partial derivative of the distance function with respect to $x_{i}$. As noted earlier, the first derivatives of the distance function with respect to inputs yield the normalized shadow price of that input, therefore the first line of the definition may be thought of as the ratio of the percentage change in shadow prices brought about by a one percentage change in the ratio of inputs. This would represent the change in relative marginal products and input prices required effecting the substitution under cost minimisation. High values reflect low substitutability and low values reflect relative ease of substitution between the inputs. We can simplify the Morishima elasticity as follows:

$$
M_{i j}=e_{i j}(\mathbf{y}, \mathbf{x})-e_{i i}(\mathbf{y}, \mathbf{x})
$$

where, $e_{i j}(\mathbf{y}, \mathbf{x})$ and $e_{i i}(\mathbf{y}, \mathbf{x})$ are the constant output cross and own elasticities of shadow prices with respect to input quantities. The first term provides information on whether pairs of inputs are net substitutes or net complements, and the second term is the own price elasticity of demand for the inputs. Here it should be noted that these elasticities are indirect elasticities. Therefore, $e_{i j}$ greater than zero indicates net complements and less than zero indicates net substitutes (in contrast, a 
direct substitution elasticity greater than zero indicates net substitutes and less than zero indicates net complements).

The Allen elasticity of substitution may be defined in terms of distance function as

$$
A_{i j}=\left[D(\mathbf{y}, \mathbf{x}) D_{i j}(\mathbf{y}, \mathbf{x}) / D_{i}(\mathbf{y}, \mathbf{x}) D_{j}(\mathbf{y}, \mathbf{x})\right]
$$

Here it should be noted that the Morishima and Allen elasticities yield the same result in the two-input case; when the number of inputs exceeds two, however, they no longer coincide. Moreover, the Morishima elasticities may not be symmetric, i.e., $M_{i j} \neq M_{j i}$. This is as it should be and allows for the asymmetry in the substitutability of different inputs, e.g., substitutability between skilled and unskilled personnel.

The returns to scale RTS measure can be calculated from the input distance function using the formula:

$$
R T S(\mathbf{y}, \mathbf{x})=\frac{\partial \ln \zeta}{\partial \ln \xi}=\frac{-1}{\nabla_{y} D(\mathbf{y}, \mathbf{x})}
$$

where, $\varsigma$ and $\xi$ are scalars representing equi-proportionate changes in the output and in the input vectors, respectively.

\section{Estimation Model}

The distance functions can be computed either nonparametrically using the Data Envelope Analysis (DEA) or parametrically. Here we adopt the parametric approach for the computation of distance functions, the advantage of this approach is that it is differentiable. We employ the translog form of input distance function that is twice differentiable and flexible. The form is given by 
$\ln D(\mathbf{x}, \mathbf{y})=\alpha_{0}+\sum_{n=1}^{N} \alpha_{n} \ln \mathbf{x}_{n}+\sum_{m=1}^{M} \beta_{m} \ln \mathbf{y}_{m}+\frac{1}{2} \sum_{n=1}^{N} \sum_{n=1}^{N} \alpha_{m} \ln \mathbf{x}_{n} \ln \mathbf{x}_{i}+\sum_{2}^{1} \sum_{m \in=}^{M} \sum_{m i}^{M} \ln \mathbf{y}_{m} \ln \mathbf{y}_{m}$ $+\sum_{n=m=1}^{N M} \gamma_{m} \ln \mathbf{y}_{m} \ln \mathbf{x}_{n}$

To compute the parameters of equation (11), we use the linear programming approach developed by Aigner and Chu (1968), that is

Minimize $\sum_{k=1}^{K}\{\ln D(\mathbf{x}, \mathbf{y})-\ln 1\}, k=1,2, \ldots . . K$.

Subject to (i) $\ln D(\mathbf{x}, \mathbf{y}) \geq 0$

(ii) $\frac{\partial \ln D(\mathbf{x}, \mathbf{y})}{\partial \ln y_{m}} \leq 0, m=1, \ldots \ldots, M$.

(iii) $\frac{\partial \ln D(\mathbf{x}, \mathbf{y})}{\partial \ln x_{n}} \geq 0, n=1, \ldots \ldots ., N$.

(iv) $\sum_{n=1}^{N} \alpha_{n}=1, \sum_{n^{\prime}=1}^{N} \alpha_{n n^{\prime}}=\sum_{n=1}^{N} \gamma_{n m}=0, n, n^{\prime}=1, \ldots \ldots, N$

(v) $\alpha_{n n^{\prime}}=\alpha_{n^{\prime} n}, \beta_{m m^{\prime}}=\beta_{m^{\prime} m}, n, n^{\prime}=1, \ldots \ldots, N, m, m^{\prime}=1, \ldots \ldots, M$

Where, $\mathrm{K}$ denotes the number of observations. The restrictions in (i) ensures that the value of input distance function is greater than or equal to one as the logarithm of this function are restricted to be greater than or equal to zero. Restriction in (ii) enforces the monotonocity condition of non-increasing of input distance function in good outputs, whereas the restriction in (iii) enforces that the input distance function is non-decreasing in inputs. Restriction (iv) and (v) impose the homogeneity and symmetry conditions respectively as required by the theory.

From the translog specification some characteristics of interest may be computed. We focus in particular on the price elasticities on input demands and elasticities of input demands with respect to output levels. 
The shadow price elasticities with respect to input quantities are obtained as:

$$
\begin{array}{ll}
\varepsilon_{i j}=\left[\alpha_{i j}+S_{i} S_{j}\right] / S_{i} & \text { if } i \neq j \\
\varepsilon_{i i}=\left[\alpha_{i i}+S_{i}\left(S_{i}-1\right)\right] / S_{i} & \text { if } i=i
\end{array}
$$

The Allen elasticities of substitution, $A_{i j}$, as $A_{i j}=\varepsilon_{i j} / S_{i}$ and Morishima elasticities of substitution as $M_{i j}=\varepsilon_{i j}-\varepsilon_{j j}, i \neq j$. Where $S_{i}$ is the first order derivative of the translog output distance function with respect to input $\ln x_{i}$, i.e., $S_{i}=\partial \ln D(\mathbf{x}, \mathbf{y}) / \partial \ln x_{i}$

\section{Data and Estimation Results}

The data used in this paper are from a recent survey of waterpolluting industries in India. ${ }^{\text {ix }}$ These survey data provide information of characteristics of the main plant for the three years 1996/97 to 1998/99. The data about the main plant are given for sales value, capital stock, wage bill, other material input costs and water consumption for a sample of 92 firms. The firms in the sample belong to leather, distillery, chemicals, sugar, paper and paper products, fertilizers, pharmaceuticals, drugs, petro-chemicals, iron and steel, refining, and other industries. For details on characteristics of data, see Murty and Kumar (2004). Descriptive statistics of the variables used in the study is given in Table 1. The results should be interpreted and used with caution since the sample may not be representative of the Indian water industry.

In order to compute absolute (undeflated) producer shadow price for water, the input distance function is estimated using equations (11) and (12) with data from 1996/97 to 1998/99 for 92 manufacturing firms. To capture industry and time effects we have included ten dummy variables. The first two dummy variables are for the time effect as we have data for three years and the next eight dummy variables are industry specific since the whole data belongs to nine industries. ${ }^{\mathrm{X}}$ Since a single distance function is estimated, input and output substitution 
possibilities are constant over time and across industries. The estimation also included tests of regularity conditions. For each observation, monotonicity with respect to inputs and outputs is imposed by the linear programming problem. The distance function satisfies convexity in outputs for most observations, while it also appears to satisfy concavity in inputs for a majority of observations. The parameter estimates are presented in Table 2.

\section{Technical Efficiency}

Recall that the input distance function is the reciprocal of the input based measure of technical efficiency. The parameter estimates of input distance function were used to compute the value of input distance function and shadow price of water for each observation. On average the technical efficiency for our sample observations is 0.46 with 0.26 standard deviation. This reflects that on average the firms can produce the same level of output with less than half of the inputs if they were operating at the input frontier. Moreover, we also observe that there is wide variation in the measure of technical efficiency across industries and firms. The least efficient industry in our sample is chemicals, which has the mean technical efficiency only 0.34 with standard deviation 0.23 , and leather is the most efficient one with mean technical efficiency 0.64 and standard deviation 0.24 . Industry wide mean and standard deviation of technical efficiency are presented in Table 3.

\section{Shadow Price of Water}

Undeflated shadow price of water is computed using equation 6. Recall that the computation of shadow price of industrial use of water requires the assumption that the observed price of one of the inputs is equal to its shadow price. Here we have obtained the shadow price of water relative to the price of materials. Table 3 provides estimates of industry-specific shadow prices for water; based on the parameters of the translog input distance function estimated using the programming approach. These shadow prices are positive, reflecting that water is a normal input in the production process of these industries. For instance, the average shadow price for water is rupees 7.21 per kilolitre. There is a wide variation of shadow prices of water across the firms and across the industries as shown in table 3 . This wide variation can be explained by the variation in the degree of water intensity as measured by the ratio of 
water consumption and sales value. The shadow price of water is found to be increasing with the degree of water intensity of firms. The correlation coefficient between the shadow price of water and water intensity for our sample firms is found to be 0.32 . The correlation coefficient is 0.68 for the firms in which the intensity of water is less than one kilolitre of water per rupee of output and it is 0.14 for the firms in which the water intensity is more than one kilolitre between water intensity and shadow prices of water. It implies that higher the lower intensity, higher would be the shadow prices. But we observe also that there is positive correlation between the absolute quantity of water used in a firm and shadow prices of water for the firm.

\section{Economies of Scale}

The measure of scale economies may be estimated for each firm in the sample using equation 10 . Table 3 , column 5 provides estimates of scale economies of water consuming industries in the sample. Two questions are of interest concerning the results of testing for scale economies of production:

1. Are the firms in the sample generally operating under conditions of increasing, neutral, or decreasing economies of scale? In the sample, the average figure for this is 1.418 .

2. Does any systematic difference in scale economies exist for different firms/industries in the sample (for example are higher levels of turnover/production associated with increasing or decreasing scale economies)? In the sample of 92 firms, the correlation coefficient is 0.71 .

\section{Analysis of Derived Demand for Water}

The distance function estimate enables us to derive the cross and own price elasticities. Here we should recall that we measure indirect elasticities. A higher value implies less responsiveness and lower values means more responsiveness. Table 4 presents the mean of these elasticities. We discuss now these results and more carefully analyse those dealing with the water input.

All own price elasticities have the expected negative sign, implying that an inverse relationship between the price of an input and its 
quantity demanded. The derived demand for materials is more elastic in comparison to other inputs. We observe relatively high labour own price elasticity compared to capital. Regarding cross price elasticities between inputs, labour appears to be complement to all other inputs, i.e., materials, capital, and water. Like that materials appear to be complement to all other inputs, but capital appears to be complement to materials and labour, and a substitute for water.

Considering now the water input, water is found to be substitute for capital, and a complement to materials and labour. Substitution between capital and water was also observed by Dupont and Renzetti (2001) and Feres and Reynaud (2003), in contrast with previous results from Grebenstein and Field (1979) and Babin, Willis and Allen (1982), where water was found to be a substitute for labour and a complement to capital.

It should be noticed that the own price elasticity of water is quite high, -0.902 (in conventional sense it is -1.11) at the sample mean with standard deviation (0.16). The result suggests that pricing policies can be a potential instrument for water conservation. This elasticity is close to the one obtained by Wang and Lall (2002) for the Chinese economy, who estimates an average price elasticity of approximately -1.0 ; and by Feres and Reynaud (2003) for the Brazilian economy, who estimates an average price elasticity of approximately -1.078 . However, since Wang and Lall (2002) adopts a marginal productivity approach and Feres and Reynaud (2003) adopts cost function approach to derive elasticity estimates, any comparison between elasticity estimates should be made with caution. The estimates of own price elasticity of water for India, China and Brazil are higher than those obtained by Onjala (2001) for Kenya and Goldar (2003) for India. Onjala estimates water price elasticities ranging from -0.60 to 0.37 . Goldar estimates water price elasticities ranging from -0.4 to 0.64 . Onjala (2001) adopts a dynamic adjustment model with data on input prices and production levels, whereas Goldar adopts marginal productivity approach with aggregate data on inputs and outputs and water input data includes only the quantity of water purchased and not of water consumed. However, once more comparison between estimates seems to be difficult to establish and results should be used with caution.

The water price elasticity estimates for developing countries (India, Brazil and China) are significantly higher than the ones obtained 
for developed countries (U.S., Canada and France). For example, for the U.S. manufacturing sector Grebenstein and Field (1979) finds elasticities ranging from -0.80 to -0.33 ; Babin, Willis and Allen (1982) finds elasticities ranging from -0.66 to +0.14 ; for the Canadian manufacturing Renzetti (1992) finds elasticities ranging from -0.59 to -0.15 ; Dupont and Renzetti (2001) finds elasticity -0.77 ; and for French manufacturing, Reynaud (2003) finds elasticity -0.29 .

It is quite difficult to attribute these differences between developing and developing countries water price elasticities to any structural based explanation or it is due to the difficulties of getting accurate water related data in developing countries. Indeed, the water price used in our study corresponds to the marginal cost whereas the prices paid by Indian firms are far below this level. ${ }^{\mathrm{xi}}$ This may lead to an upward bias in our estimates. The same upward bias could be present in Wang and Lall (2002) and Feres and Reynaud (2003). Moreover, the three samples (Indian, Chinese and Brazilian) are composed by medium and large plants, which tend to have higher water price elasticities than small ones. Since large firms withdraw high volumes of water, they face high incentives to invest in water-recycling activities. Water recirculation being a substitute to water withdrawal, these firms should have a more elastic water withdrawal price elasticity (Reynaud, 2003). In developing countries, it should be noticed that water is not a scarce resource in the sense that firms do not face any stringent water resource constraint in these countries as water is oftenly under priced or unpriced intermediate input. In such a context, firms are likely to overuse water resources and the marginal productivity of the water tends to be low, as reported by Wang and Lall (2002). This may result in high responsiveness to water prices, since any increase in water prices would lead to substantial cut in water withdrawals, although additional research and more accurate data on industrial use of water in developing countries is needed in order to answer these questions.

The indirect Morishima and Allen elasticities of substitution can be computed from own and price elasticities and they are presented in Tables 5 and 6 respectively. In the sense of Morishima elasticities all of the inputs appears to be complement to each other, whereas according to Allen elasticities of substitution water and capital are substitute to each other and all other inputs appears to be complements. 


\section{Analysis by Industry Type}

Table 7 presents the indirect own and cross elasticities of input derived demand. These elasticities are computed at the mean sample for each industrial sector.

The own price elasticity of water ranges from -0.301 for drug and pharmaceutical sector to -0.942 for leather industry, means that the own price elasticity is not much different across sector except drug and pharmaceutical, and it is price elastic for all the sectors. The own price elasticity for labour is not much different across industries and it ranges between 0.505 to -0.529 . Like that own price elasticity for materials ranges between -0.203 to -0.320 . Concerning cross price elasticities, water appears to be a substitute for capital and a complement to materials and labour in all the industries.

\section{Conclusions}

This paper investigates the structure of industrial water demand in India. We have estimated production technology with an input distance function, which is dual to the more commonly used cost function. This duality is employed to retrieve the shadow price of water. The advantage of using the distance function approach instead of cost function approach is that one can calculate elasticities of substitution without the maintained axiom of cost minimisation, including Morishima elasticities of substitution. We have estimated derived demand for water using the establishment-level data for 92 firms belonging to different industries over the three-year period. In our empirical model, water, as well as capital, labour and materials are treated as input to industrial production (sales revenue). Translog functional form is specified for the input distance function with dummies for year and industry specific characteristics.

In the literature, cost, production and demand functions have been used to estimate the derived demand of industrial water use. These three approaches are based on the maintained axioms of optimisation 
and assume that firms are operating at their frontiers, and cost and demand functions require established market for water and information regarding costs and prices. In the absence of well established water market and information about prices and cost, the distance function approach can be used to asses the shadow prices of water for industrial use if information about quantities of inputs and outputs is available when firms are not operating at their frontiers. Thus the distance function also provides estimates of firm's efficiency and returns to scale.

The main results of our analysis are the following. We first have shown that there is high variability in the production efficiency of Indian firms, they can produce the same level of output with less than half of the quantities of inputs that they are using on average. There is increasing returns to scale in our sample of firms with an average of 1.42 and returns to scale is positively associated with turnover and water intensity. The estimated average shadow price of water is rupees 7.21 per kilolitre. We observe a wide variation across industries and firms in these shadow prices. The shadow price varies from rupees 1.40 per kilolitre for petrochemicals to rupees 30.54 per kilolitre for paper and paper products industry.

We have also estimated own and cross price elasticities of water for other inputs. We find that water is a complement to labour and materials and a substitute to capital. We find a price elasticity of water demand about -0.902 (in conventional sense -1.11) at the sample mean. This high value is similar to what has been found by other researchers working on developing countries (for example, China and Brazil). Thus, given the high responsiveness of water demand to price, water charges may act as an effective instrument for water conservation. 
Table 1: Descriptive Statistics of the Variables Used in the Estimation

\begin{tabular}{llllll}
\hline & $\begin{array}{l}\text { Sales } \\
\text { Revenue } \\
\text { (Rs. } \\
\text { million) }\end{array}$ & $\begin{array}{l}\text { Materials. } \\
\text { million) }\end{array}$ & $\begin{array}{l}\text { Wage } \\
\text { Bill (Rs. Stock } \\
\text { illion) }\end{array}$ & $\begin{array}{l}\text { Capital } \\
\text { (Rs. million) }\end{array}$ & $\begin{array}{l}\text { Water } \\
\text { (million } \\
\text { kilolitre) }\end{array}$ \\
\hline Mean & 1911.59 & 774.23 & 169.79 & 2323.67 & 1676.91 \\
Maximum & 25190.00 & 11143.58 & 10080.00 & 74538.09 & 37172.41 \\
Minimum & 0.38 & 0.52 & 0.14 & 0.33 & 0.04 \\
Std. Dev. & 3291.95 & 1382.05 & 794.93 & 7811.52 & 4403.29 \\
Observations & 276 & 276 & 276 & 276 & 276 \\
\hline
\end{tabular}

Table 2: Parameter Estimates of Translog Input Distance Function

\begin{tabular}{|c|c|c|c|}
\hline Variable & $\begin{array}{l}\text { Coefficien } \\
\mathrm{t}\end{array}$ & Variable & Coefficient \\
\hline Constant & 0.415 & Capital Stock $\times$ Water & -0.002 \\
\hline Materials & 0.424 & Water $^{2}$ & 3.67E-04 \\
\hline Wage Bill & 0.373 & Sales Revenue $^{2}$ & 0.018 \\
\hline Capital Stock & 0.196 & Year 1 dummy & 0.135 \\
\hline Water & 0.007 & Year 2 dummy & 0.043 \\
\hline Sales Revenue & -0.824 & Leather dummy & 0.205 \\
\hline Materials $^{2}$ & 0.097 & Distillery dummy & 1.102 \\
\hline $\begin{array}{l}\text { Materials } \times \text { Wage } \\
\text { Bill }\end{array}$ & -0.062 & Chemicals dummy & 0.448 \\
\hline $\begin{array}{l}\text { Materials } \times \text { Capital } \\
\text { Stock }\end{array}$ & -0.036 & Sugar Dummy & 0.356 \\
\hline Materials $\times$ Water & 0.001 & $\begin{array}{l}\text { Paper and paper } \\
\text { products dummy }\end{array}$ & -0.145 \\
\hline Wage Bill $^{2}$ & 0.053 & Fertilizer dummy & -0.241 \\
\hline $\begin{array}{l}\text { ///Wage } \\
\text { Bill×Capital Stock }\end{array}$ & 0.008 & $\begin{array}{l}\text { Drug and Pharmaceutical } \\
\text { dummy }\end{array}$ & 2.136 \\
\hline $\begin{array}{l}\text { Wage Bill } \times \text { Water } \\
\text { Capital Stock }^{2}\end{array}$ & $\begin{array}{l}3.87 \mathrm{E}-04 \\
0.03\end{array}$ & Petro-chemicals dummy & -0.427 \\
\hline
\end{tabular}


Table 3: Technical Efficiency, Shadow Price of Water, and Return to scale by Industry.

\begin{tabular}{|c|c|c|c|c|}
\hline $\begin{array}{l}\text { Name of } \\
\text { Industry }\end{array}$ & $\begin{array}{l}\text { Number of } \\
\text { observations }\end{array}$ & $\begin{array}{l}\text { Technical } \\
\text { efficiency }\end{array}$ & $\begin{array}{l}\text { Shadow } \\
\text { Price of } \\
\text { water }\end{array}$ & RTS \\
\hline Leather & 09 & $\begin{array}{l}0.637 \\
(0.239)\end{array}$ & $\begin{array}{l}1.161 \\
(0.950)\end{array}$ & $\begin{array}{l}1.365 \\
(0.037)\end{array}$ \\
\hline Distillery & 18 & $\begin{array}{l}0.393 \\
(0.229)\end{array}$ & $\begin{array}{l}6.752 \\
(6.620)\end{array}$ & $\begin{array}{l}1.362 \\
(0.062)\end{array}$ \\
\hline Chemicals & 48 & $\begin{array}{l}0.343 \\
(0.216)\end{array}$ & $\begin{array}{l}3.164 \\
(5.872)\end{array}$ & $\begin{array}{l}1.436 \\
(0.033)\end{array}$ \\
\hline Sugar & 114 & $\begin{array}{l}0.424 \\
(0.235)\end{array}$ & $\begin{array}{l}4.862 \\
(8.907)\end{array}$ & $\begin{array}{l}1.404 \\
(0.051)\end{array}$ \\
\hline $\begin{array}{l}\text { Paper and } \\
\text { Paper } \\
\text { Products }\end{array}$ & 33 & $\begin{array}{l}0.630 \\
(0.224)\end{array}$ & $\begin{array}{l}30.535 \\
(32.632)\end{array}$ & $\begin{array}{l}1.435 \\
(0.027)\end{array}$ \\
\hline Fertilizers & 18 & $\begin{array}{l}0.442 \\
(0.217)\end{array}$ & $\begin{array}{l}2.465 \\
(3.192)\end{array}$ & $\begin{array}{l}1.465 \\
(0.048)\end{array}$ \\
\hline $\begin{array}{l}\text { Drug and } \\
\text { Pharmaceu } \\
\text { ticals }\end{array}$ & 06 & $\begin{array}{l}0.514 \\
(0.505)\end{array}$ & $\begin{array}{l}3.919 \\
(3.609)\end{array}$ & $\begin{array}{l}1.337 \\
(0.036)\end{array}$ \\
\hline $\begin{array}{l}\text { Petro- } \\
\text { chemicals }\end{array}$ & 09 & $\begin{array}{l}0.516 \\
(0.386)\end{array}$ & $\begin{array}{l}1.396 \\
(1.682)\end{array}$ & $\begin{array}{l}1.431 \\
(0.023)\end{array}$ \\
\hline Misc. & 21 & $\begin{array}{l}0.546 \\
(0.285)\end{array}$ & $\begin{array}{l}3.026 \\
(4.995)\end{array}$ & $\begin{array}{l}1.470 \\
(0.046)\end{array}$ \\
\hline All & 276 & $\begin{array}{l}0.455 \\
(0.260)\end{array}$ & $\begin{array}{l}7.209 \\
(15.611)\end{array}$ & $\begin{array}{l}1.418 \\
(0.054)\end{array}$ \\
\hline
\end{tabular}

Note: Figures in parentheses are standard deviations 
Table 4: Mean of Cross and Own Indirect Price Elasticity of Input Demands, $\left(\varepsilon_{i j}\right)$

\begin{tabular}{|c|c|c|c|c|}
\hline & Materials & Wage bill & \multicolumn{2}{|c|}{$\begin{array}{l}\text { stoc } \\
\mathrm{k}\end{array}$} \\
\hline Materials & $\begin{array}{l}-0.268 \\
(0.083)\end{array}$ & $\begin{array}{l}0.144 \\
(0.056)\end{array}$ & $\begin{array}{l}0.117 \\
(0.040)\end{array}$ & $\begin{array}{l}0.008 \\
(0.002)\end{array}$ \\
\hline Wage bill & $\begin{array}{l}0.292 \\
(0.057)\end{array}$ & $\begin{array}{l}-0.522 \\
(0.027)\end{array}$ & $\begin{array}{l}0.220 \\
(0.041)\end{array}$ & $\begin{array}{l}0.007 \\
(0.003)\end{array}$ \\
\hline Capital stock & $\begin{array}{l}0.270 \\
(1.064)\end{array}$ & $\begin{array}{l}0.328 \\
(0.239)\end{array}$ & $\begin{array}{l}-0.589 \\
(0.890)\end{array}$ & $\begin{array}{c}-0.009 \\
(0.060)\end{array}$ \\
\hline Water & $\begin{array}{l}0.788 \\
(0.409)\end{array}$ & $\begin{array}{l}1.239 \\
(1.690)\end{array}$ & $\begin{array}{l}-0.313 \\
(0.845)\end{array}$ & $\begin{array}{l}-0.902 \\
(0.158)\end{array}$ \\
\hline
\end{tabular}

Note: Figures in parentheses are standard deviations

Table 5: Mean of Morishima Elasticity of Substitution, $\left(M_{i j}\right)$

Materials Wage bill Capital Water

\begin{tabular}{lllll} 
Materials & 0 & 0.666 & 0.706 & 0.910 \\
& & $(0.068)$ & $(0.900)$ & $(0.158)$ \\
Wage bill & 0.561 & 0 & 0.809 & 0.909 \\
& $(0.101)$ & & $(0.900)$ & $(0.159)$ \\
Capital stock & 0.539 & 0.850 & 0 & 0.893 \\
& $(1.081)$ & $(0.233)$ & & $(0.167)$ \\
Water & 1.056 & 1.762 & 0.276 & 0 \\
& $(0.406)$ & $(1.683)$ & $(1.224)$ & \\
\hline
\end{tabular}

Note: Figures in parentheses are standard deviations 
Table 6: Mean of Allen Elasticity of Substitution, $\left(A_{i j}\right)$

\begin{tabular}{lllll}
\hline & Materials & Wage bill & $\begin{array}{l}\text { Capital } \\
\text { stock }\end{array}$ & Water \\
\hline Materials & 0 & 0.258 & 0.216 & 0.016 \\
& & $(0.465)$ & $(0.251)$ & $(0.018)$ \\
Wage Bill & 1.175 & 0 & 0.853 & 0.030 \\
& $(0.384)$ & & $(0.215)$ & $(0.015)$ \\
Capital Stock & -29.750 & 9.336 & 0 & -1.848 \\
& $(520.918)$ & $(125.336)$ & & $(29.915)$ \\
Water & 369.495 & 1039.308 & -442.696 & 0 \\
& $(2403.71)$ & $(8930.628)$ & $(4417.971)$ & \\
\hline
\end{tabular}

Note: Figures in parentheses are standard deviations

Table 7: Price Elasticities by Industry $\left(\varepsilon_{i j}\right)$

\begin{tabular}{|c|c|c|c|c|c|c|c|c|c|}
\hline \multirow{2}{*}{\multicolumn{2}{|c|}{$\begin{array}{r}\text { Mat } \\
\text { Leather (09) }\end{array}$}} & e & ap & Vater & & Mat & 120 & ap & $\overline{e r}$ \\
\hline & & & & & \multicolumn{5}{|c|}{ Fertilizers (18) } \\
\hline at & $\begin{array}{l}-0.203 \\
(09)\end{array}$ & 13 & $\begin{array}{l}0.080 \\
(0.05)\end{array}$ & 10 & Mat & $\begin{array}{l}-0.279 \\
(0.05)\end{array}$ & $(0$ & & \\
\hline Vage & $\begin{array}{l}0.3 \\
0 .\end{array}$ & & & & e & & & & \\
\hline Sap & & & & & Cap & & & & \\
\hline Distiller & $\begin{array}{l}0.778 \\
(0.09) \\
y(18)\end{array}$ & 0.736 & -0.133 & $\begin{array}{l}-0 \\
(0\end{array}$ & Drug a & $\begin{array}{c}0.745 \\
(0.06) \\
\text { nd Pharr }\end{array}$ & $\begin{array}{c}1.088 \\
(0.32) \\
\text { maceutic }\end{array}$ & $\begin{array}{c}-0.228 \\
(0.11) \\
\text { cal }(06)\end{array}$ & \\
\hline 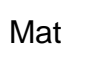 & & & & & Mat & & & & \\
\hline lage & 0.268 & $\begin{array}{l}-0.516 \\
(0.02)\end{array}$ & $\begin{array}{l}0.239 \\
(0.04)\end{array}$ & & Wage & $\begin{array}{l}.251 \\
.08)\end{array}$ & & & \\
\hline ap & & & $\begin{array}{l}-0.639 \\
(0.01)\end{array}$ & & Cap & & & & \\
\hline Chemic & $\begin{array}{c}0.711 \\
(0.11) \\
\text { aals }(48)\end{array}$ & 1.159 & -0.235 & -0.9 & Water & $\begin{array}{c}2.389 \\
(2.45) \\
\text { Chemica }\end{array}$ & $\begin{array}{l}7.607 \\
(10) \\
\text { Is }(09)\end{array}$ & & \\
\hline 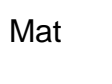 & & & & & 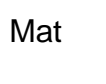 & & & & \\
\hline Nage & 0.283 & -0.517 & 0.225 & 0.007 & $\mathrm{e}$ & & & & \\
\hline
\end{tabular}




\begin{tabular}{|c|c|c|c|c|c|c|c|c|c|}
\hline & Mat & Wage & Cap & Water & & Mat & Wage & Cap & Water \\
\hline Cap & $\begin{array}{l}0.325 \\
(0.08)\end{array}$ & $\begin{array}{l}0.326 \\
(0.07)\end{array}$ & $\begin{array}{l}-0.646 \\
(0.01)\end{array}$ & $\begin{array}{l}-0.005 \\
(0.001)\end{array}$ & Cap & $\begin{array}{l}0.388 \\
(0.08)\end{array}$ & $\begin{array}{l}0.259 \\
(0.07)\end{array}$ & $\begin{array}{l}-0.640 \\
(0.02)\end{array}$ & $\begin{array}{l}-0.007 \\
(0.002)\end{array}$ \\
\hline Water & 0.732 & $\begin{array}{l}1.117 \\
(06)\end{array}$ & $\begin{array}{l}-0.236 \\
(0.28)\end{array}$ & $\begin{array}{l}-0.915 \\
(0.05)\end{array}$ & & $\begin{array}{l}0.827 \\
(0.16)\end{array}$ & $\begin{array}{l}1.021 \\
(0.45)\end{array}$ & $\begin{array}{l}-0.251 \\
(0.22)\end{array}$ & $\begin{array}{l}-0.917 \\
(0.04)\end{array}$ \\
\hline \multicolumn{5}{|c|}{ Sugar (114) } & \multicolumn{5}{|c|}{ Misc. (21) } \\
\hline Mat & $\begin{array}{l}-0.247 \\
(0.1)\end{array}$ & $\begin{array}{l}0.132 \\
(0.07)\end{array}$ & $\begin{array}{l}0.107 \\
(0.05)\end{array}$ & $\begin{array}{l}0.008 \\
(0.002)\end{array}$ & Mat & $\begin{array}{l}-0.263 \\
(0.05)\end{array}$ & $\begin{array}{l}0.125 \\
(0.03)\end{array}$ & $\begin{array}{l}0.131 \\
(0.03)\end{array}$ & $\begin{array}{l}0.006 \\
(0.002)\end{array}$ \\
\hline Wage & $\begin{array}{l}0.307 \\
(0.06)\end{array}$ & $\begin{array}{l}-0.529 \\
(0.03)\end{array}$ & $\begin{array}{l}0.211 \\
(0.04)\end{array}$ & $\begin{array}{l}0.008 \\
(0.002)\end{array}$ & Wage & $\begin{array}{l}0.289 \\
(0.04)\end{array}$ & $\begin{array}{l}-0.530 \\
(0.01)\end{array}$ & $\begin{array}{l}0.232 \\
(0.04)\end{array}$ & $\begin{array}{l}0.006 \\
(0.002)\end{array}$ \\
\hline Cap & $\begin{array}{l}0.347 \\
(0.07)\end{array}$ & $\begin{array}{l}0.303 \\
(0.05)\end{array}$ & $\begin{array}{l}-0.644 \\
(0.02)\end{array}$ & $\begin{array}{l}-0.005 \\
(0.001)\end{array}$ & Cap & $\begin{array}{l}0.370 \\
(0.05)\end{array}$ & $\begin{array}{l}0.280 \\
(0.04)\end{array}$ & $\begin{array}{l}-0.644 \\
(0.007)\end{array}$ & $\begin{array}{l}-0.006 \\
(0.001)\end{array}$ \\
\hline Water & $\begin{array}{l}0.766 \\
(0.2)\end{array}$ & $\begin{array}{l}1.059 \\
(0.89)\end{array}$ & $\begin{array}{l}-0.236 \\
(0.41)\end{array}$ & $\begin{array}{l}-0.918 \\
(0.08)\end{array}$ & Water & $\begin{array}{l}0.912 \\
(0.33)\end{array}$ & $\begin{array}{l}1.596 \\
(1.3)\end{array}$ & $\begin{array}{l}-0.505 \\
(0.65)\end{array}$ & $\begin{array}{l}-0.867 \\
(0.12)\end{array}$ \\
\hline \multicolumn{10}{|c|}{ Paper and Paper Products (33) } \\
\hline Mat & $\begin{array}{l}-0.320 \\
(0.04)\end{array}$ & $\begin{array}{l}0.187 \\
(0.03)\end{array}$ & $\begin{array}{l}0.124 \\
(0.04)\end{array}$ & $\begin{array}{l}0.009 \\
(0.003)\end{array}$ & & & & & \\
\hline Wage & $\begin{array}{l}0.272 \\
(0.05)\end{array}$ & $\begin{array}{l}-0.510 \\
(0.02)\end{array}$ & $\begin{array}{l}0.228 \\
(0.05)\end{array}$ & $\begin{array}{l}0.008 \\
(0.003)\end{array}$ & & & & & \\
\hline Cap & $\begin{array}{l}0.276 \\
(0.06)\end{array}$ & $\begin{array}{l}0.365 \\
(0.05)\end{array}$ & $\begin{array}{l}-0.636 \\
(0.02)\end{array}$ & $\begin{array}{l}-0.004 \\
(0.002)\end{array}$ & & & & & \\
\hline Water & $\begin{array}{l}0.681 \\
(0.16)\end{array}$ & $\begin{array}{l}1.146 \\
(0.67)\end{array}$ & $\begin{array}{l}-0.223 \\
(0.32)\end{array}$ & $\begin{array}{l}-0.915 \\
(0.06)\end{array}$ & & & & & \\
\hline
\end{tabular}




\section{References}

Aigner, D.J. and S.F. Chu (1968), 'Estimating the industry production function', American Economic Review 58: 826-39.

Arbues, F., Mar'ýa Ángeles Garc'ýa-Valiñas, Roberto Mart'ýnezEspiñeira (2003), 'Estimation of residential water demand: a state-of-the-art review', Journal of Socio-Economics 32: 81-102.

Babin, F., C. Willis and G. Allen (1982), 'Estimation of substitution possibilities between water and other production inputs', American Journal of Agricultural Economics 64: 148151.

Bhatia, R., P. Rogers, J. Briscoe, B. Sinha and R. Cestti (1994), 'Water conservation and pollution control in Indian industries: how to use water tariff, pollution charges and fiscal incentives', Currents, UNDP-World Bank, Water and Sanitation Programme.

Blackorby, C., and R. R. Russell (1989), 'Will the real elasticity please stand up?' American Economic Review 79: 882-888.

DeRooy, Y. (1974), 'Price responsiveness of the industrial demand for water', Water Resources Research, 10: 403-406.

Dupont, D. P. and S. Renzetti (2001), 'The role of water in manufacturing', Environmental and Resource Economics 18: $411-432$.

Fare, R. and S. Grosskopf and C.A.K. Lovell (1994), Production Frontiers, Cambridge University Press, Cambridge.

Fare, R. and D. Primont (1995), Multi-Output Production and Duality: Theory and Applications, Kluwer Academic Publishers, Netherlands.

Feres, Jose and A. Reynaud (2003), 'Industrial water use, cost structure and environmental policy in Brazil', available at http:Ilwww.sbe.org.br/ebe25/056.pdf 
Frederick, K. D., T. Vandenberg, and J. Hanson (1997), 'Economic Values of Freshwater in the United States', Discussion Paper no. 97-03, Resources for the Future, Washington.

Goldar, B.N. (2003), 'Water use in Indian industry: estimates of value and price elasticity of demand', in K. Chopra, C. H. Hanumantha Rao and R. Sengupta (eds), Resources, Sustainable Livelihoods and Eco-System Services, New Delhi: Concept Publishing Company.

Goldar, B.N. and R. Pandey (2001), 'Water pricing and abatement of industrial water pollution: study of distilleries in India', Environmental Economics and Policy Studies, 4: 95-113.

Grebenstein, C. and B. Field (1979), 'Substituting for water inputs in U.S. manufacturing', Water Resource Research 15: 228-232.

Grosskopf, S., K. Hayes and J. Hirschberg (1995), 'Fiscal stress and the production of public safety: a distance function approach', Journal of Public Economics, 57: 277-296.

Gupta, D.B., M.N. Murty and R. Pandey (1989), 'Water conservation and pollution abatement in Indian industry- a case study of water tariff', Mimeo. National Institute of Public Finance and Policy, New Delhi.

Johansson, R.C., Y. Tsur, T.L. Roe, R. Doukkali and A. Dinar (2002), 'Pricing irrigation water: a review of theory and practice', Water Policy 4: 173-199.

Murty, M.N. and Surender Kumar (2004) Environmental and Economic Accounting for Industry, Oxford University Press, New Delhi

Onjala, J. (2001), 'Industrial water demand in Kenya: industry behaviour when tariffs are not binding', Mimeo, Roskilde University, Danemark, available at: http:|lwww.environmentaleconomics.dk/papers/waterkenya.pdf 
Rees, J. (1969) Industrial Demand of Water: A Study of South East England, Weidenfeld and Nicolson, London.

Renzetti, S. (1988), 'An econometric study of industrial water demands in British Columbia, Canada', Water Resources Research 24: 1569-1573.

Renzetti, S. (1992), 'Estimating the structure of industrial water demands: the case of Canadian manufacturing', Land Economics 68: 396-404.

Renzetti, S. (1993), 'Examining the differences in self and publicly supplied firm's water demands', Land Economics 69: 181-188.

Renzetti, S. (2002), 'The Economics of Industrial Water Use: The Management of Water Resources. Edward Edgard.

Reynaud, A. (2003), 'An econometric estimation of industrial water demand in France', Environmental and Resource Economics 25: 213-232.

Turnovsky, S. (1969), 'The demand for water: some empirical evidence on consumers' response to a commodity in uncertain supply', Water Resources Research 5: 350-361.

Varela-Ortega, C., J. Sumpsi, A. Garrido, M. Blanco and E. Iglesias (1998), 'Water pricing policies, public decision making and farmers' response: implications for water policy', Agricultural Economics 19, 193-202.

Wang, H., and S. Lall (2002), 'Valuing water for Chinese industries: a marginal productivity analysis', Applied Economics 34: 759-765.

Williams, M. and B. Suh (1986), 'The demand for urban water by customer class', Applied Economics 18: 1275-1289.

Ziegler, J. and S. Bell (1984), 'Estimating demand for intake water by self-supplied firms', Water Resource Research 20: 4-8. 


\section{Endnotes}

i On survey of agricultural use of water and its pricing see, Varela-Ortega (1998) and Johansson et al. (2002).

ii On survey of residential water demand see, Arbues et al. (2003).

iii Frederick et al. (1997) report only 7 estimates that deal with industrial water use in 494 estimates of economic value of freshwater in a survey for the US. In the context of developing countries we could locate only few studies which are devoted to the analysis of demand for industrial water use; i.e., Onjala (2001); Wang and Lall (2002); and Feres and Reynaud (2003), Goldar (2003) etc.

iv Turnoskvsky, 1969; Rees, 1969; DeRoy, 1974; etc.

$\checkmark$ Grebenstein and Field, 1979; Babin, Willis and Allen, 1982; Ziegler and Shu, 1984; Williams and Shu, 1986; Renzetti, 1988; Renzetti, 1992; Renzetti, 1993; Dupont and Renzetti, 2001; Renzetti, 2002, Reynaud, 2003; Feres and Reynaud, 2003; etc.

${ }^{v i}$ For the properties of input distance function; see Fare and Primont (1995).

vii To the extent that markets are imperfectly competitive, or there are subsidies or taxes, the assumption that the shadow price and observed prices are equal is inaccurate.

viii The radial projection assumed a proportional contraction of all inputs for given outputs vector until the isoquant is attained.

${ }^{i x}$ A Survey of Water Polluting Industries in India, Research Project on

'Environmental and Economic Accounting for Industry', Institute of Economic Growth, Delhi (2000).

${ }^{x}$ In our sample of 276 observations and there are 114 observations that belong to sugar industry. Therefore, we have tried to estimate the distance function parameters without sugar industry and only for sugar industry, but the results were not statistically different from the estimates obtained from the whole sample. This may be due to introduction of industry specific dummy variables since linear programming is sensitive to outliers.

xi Gupta et al. (1989) has estimated the financial cost of groundwater extraction rupees 0.25 per kilolitre, therefore, Goldar and Pandey (2001) are of the view that the price of water in India often does not cover the cost of delivery, let alone its opportunity cost or scarcity value. This results in overuse/wasteful use of water. 